17. Louis Leon Thurstone. Режим доступу: https://brocku.ca/ «Theory of Attitude Measurement». MeadProject/Thurstone/Thurstone_1929b.ht Psychological Review 36 (1929): 222-241. - ml

УДК 656.071.3(477)

\title{
ТЕОРЕТИЧНІ ПІДХОДИ ДО ДЕРЖАВНОГО УПРАВЛІННЯ І АДМІНІСТРУВАННЯ ЗАЛІЗНИЧНОГО ТРАНСПОРТУ УКРАЇНИ
}

\author{
Дейнека О.Г., д.е.н., професор,
}

Каплієнко А.Л., магістрант програми ТЕМПУС (УкрДУЗТ)

В статті розглянуто теоретичні та методичні підходи до державного управління і адміністрування залізничного транспорту України. Покреслено значучість залізничного транспорту як природної монополії, проаналізовані підходи до єдності иілей управління. Проведений систематичний аналіз праць з державного регулювання управління $i$ адміністрування. Виділені змістовні характеристики залізничного транспорту та функиї державного регулювання, управління $i$ адміністрування. Розкриті наукові підходи до розв'язування конкретних задач ПАТ «Украӥнська залізниия».

Ключові слова: публічне управління $\boldsymbol{i}$ адміністрування , державне регулювання транспорту, механізм державного регулювання, організаційний механізм.

\section{ТЕОРЕТИЧЕСКИЕ ПОДХОДЫ К ГОСУДАРСТВЕННОМУ УПРАВЛЕНИЮ И АДМИНИСТРИРОВАНИЮ ЖЕЛЕЗНОДОРОЖНЕГО ТРАНСПОРТА УКРАИНЫ}

\author{
Дейнека О.Г., д.э.н., профессор, \\ Каплиенко А.Л., магистрант программы ТЕМПУС (УкрГУЖТ)
}

B cтатье рассмотрень теоретические $u$ методические подходы $\kappa$ государственному управлению и администрированию железнодорожного транспорта Украины. Подчеркнуто значение железнодорожного транспорта как естественной монополии, проанализированы подходы к единству целей управления. Проведенн анализ трудов по государственному регулированию управлению и администрированию. Выделены содержательные характеристики железнодорожного транспорта и функции государственного регулирования, управления и администрирования .Раскрыты научные подходы к решению конкретных задач ПАО «Украинская зализныцяя.

Ключевые слова: публичное управление и администрирование, государственное регулирование транспорта, механизм государственного регулирования, организационный механизм.

(C) Дейнека О.Г., Каплієнко А.Л.
Вісник економіки транспорту і промисловості № 59, 2017 


\title{
THEORETICAL APPROACH TO THE STATE MANAGEMENT AND ADMINISTRATION OF UKRAINIAN LIQUEFIED TRANSPORT
}

\author{
Deineka O.G., Doctor of Economics, Professor, \\ Kaplienko A.L., Master of program TEMPUS (USU RT)
}

The article considers theoretical and methodological approaches to the state management and administration of Ukraine's railway transport. The values of railway transport as a natural monopoly are underlined, approaches to the unity of management objectives are analyzed. The analysis of the works on state regulation of management and administration. The substantial characteristics of the railway transport and the functions of state regulation, management and administration are highlighted. The scientific approaches to the solution of specific tasks of PJSC "Ukrainian gulf" are disclosed.

Keywords: public administration and administration, state regulation of transport, mechanism of state regulation, organizational mechanism.

Постановка проблем. Залізничний транспорт є не тільки базовою галуззю економіки, іiі “кровоносною системою”, він впливає на все життя держави, сприяючи міжрегіональним та міжнародним культурним зв'язкам, соціальним перетворенням, міжнародному туристичному співробітництву, торгівлі тощо. У сучасних умовах одним із найдинамічніших секторів української економіки $\epsilon$ залізнична галузь, яка $\epsilon$ найважливішим знаряддям ринкових перетворень, фактором розвитку економіки, засобом іï публічного управління і адміністрування.

В умовах ринкової економіки змінилася дія двох основних принципів державного регулювання публічного управління i адміністрування, a саме системності - єдності цілей та спільного

Виходячи 3 цього, постановка проблеми пошуку механізмів державного регулювання публічного управління i адміністрування розвитку вітчизняного залізничного транспорту України з позиції об'єктивного аналізу 3 урахуванням цих змін $є$ актуальною й перспективною.

Проведений нами системний аналіз наукових праць 3 державного регулювання публічного управління i адміністрування засвідчує, що проблема механізмів державного регулювання не була до цього часу предметом спеціального дослідження. Окремі праці стосуються лише певних конкретних складових цієї проблеми.

Аналіз останніх досліджень i публікацій. Важливе значення для дослідження механізмів державного регулювання публічного управління i адміністрування розвитку вітчизняного залізничного транспорту, підвищення ефективності існуючих механізмів державного регулювання цього процесу мають наукові праці таких вчених, як: Развадовський В.Й. [4,5, Марущак В.П. [3], Сущенко В.В .[6],Скворцов О.О. [7], Сорокін Г.М. [8], Сінгаєвська М.П. [9], Шакуров Р.X [2], Шепець В.М. [1], та ін.

В. Шепель, розглядаючи управління як управлінську діяльність, як низку рішень, що приймаються, звертає свою особливу увагу на те, що такі рішення мають бути морально обгрунтованими [1, с.41]. Така позиція була підтримана багатьма дослідниками, які виступили проти абсолютизації технологічного, вузькопрофесійного підходу до тлумачення категорії “управління".

Пізніше вчені розвинули цю тезу. Це сталося, коли дослідники почали вивчати феномени “суб'єкт” i “об'єкт” управління та умови гнучкої управлінської взаємодії, спрямованої на досягнення стратегічних завдань розвитку різних галузей економіки.

Вісник економіки транспорту і промисловості № 59, 2017 
у дослідженнях Р. Шакурова знаходимо переконливе твердження про те, що: “...управління $є$ регулюванням будьякої системи... для отримання потрібного результату ...”[2, с.5].

В. Марущак справедливо зауважує, що функція управління неминуче повинна виявляти цілеспрямований вплив, бо в іншому випадку управління припиняе виконувати своє основне призначення. Основу життєдіяльності управління виконує управлінність цього процесу, що і $є$ змістом функції управління. Управлінність процесу співіснування управління на практиці здійснюється шляхом принципів, засобів, каталізаторів та інших засобів, що в сукупності створюють форму функції управління. Таким чином, форма функції управління - це iii інструментарій, що забезпечує реалізацію сутності і змісту [3, с. 103].

Значний внесок у розробку моделей державного регулювання розвитку залізничного транспорту, удосконалення організаційних механізмів такого регулювання зробили вітчизняні дослідники: I. Аксьонов, В.Развадовський, Д.Тимоха, А. Ткаченко, О. Харчук, П. Яновський та ін.

Дослідники змісту поняття “державне регулювання" завжди включали в цей зміст такі категорії, як "тенденції", "керування суспільними процесами" (Г. Одінцова, Н. Мельтюхова та ін.).

Тому державне регулювання транспортною системою, зокрема залізничного транспорту, оскільки воно пов'язане 3 людьми, має керуватись запитами й потребами громадян, постійно вивчаючи свою глобальну роль у їх задоволенні. Транспорт, його небезпека все сильніше попадає в залежність від людського фактора, від готовності його працівників адаптуватись до нових технологій, більш складних умов праці, які вимагають від них високої культури стосунків, посиленого психологічного навантаження.
Отже, державне регулювання розвитку залізничного транспорту - це особлива соціальна функція, яка виникає 3 потреб суспільства, супроводить їх задоволення й відповідає державному устрою й соціуму.

Проте, незважаючи на широкий спектр досліджень і не зменшуючи їхньої вагомості й значущості, у цілому слід констатувати: стан наукового опрацювання окресленої проблеми $є$ фрагментарним. Його не можна вважати задовільним. У вітчизняній науці з державного управління бракує наукових праць, де було б викладено системне уявлення про державне регулювання розвитку залізничного транспорту України в умовах ринкового соціуму, обгрунтовано принципи та механізми регуляторного впливу держави на цей процес.

Метою статті $\mathbf{\epsilon}$ пошуком науково обгрунтованої моделі державного управління і адміністрування залізничного транспорту України, яка передбачає формування об'єктивних соціальноекономічних умов та необхідність зміни механізмів державного регулювання публічного управління і адміністрування розвитку вітчизняного залізничного транспорту; досягнення більш досконалих механізмів ефективного впливу державного регулювання на розвиток залізничного транспорту України; ліквідацію суперечливих тенденцій та причин, які гальмують розвиток залізничного транспорту України.

Виклад основного матеріалу. Змістовими характеристиками регулювання залізничного транспорту (за В. Развадовським), $є$ : його активний, цілеспрямований характер тому, що згідно ст. 3 Конституції України, права і свободи людини та їх гарантії визначають зміст i спрямованість діяльності держави. Держава відповідає перед людиною за свою діяльність. Утвердження й забезпечення прав та свобод людини $є$ головним обов'язком держави; має загальнодержавний характер, тобто

Вісник економіки транспорту і промисловості № 59, 2017 
охоплює усі сфери суспільних відносин; має виконавчо- розпорядчий, організуючий характер стосовно органів державної влади, відносин між членами суспільства. Останне держава регулює шляхом організації, упорядкування [4].

Таким чином, розбудова ринкових відносин вимагає кардинальних змін не тільки в організації державного регулювання усіма видами залізничного транспорту, але, перш за все, повністю залежить від цільових пріоритетів, що передбачає переорієнтацію державного регулювання розвитку транспорту на механізми системної модернізації: $з$ одного боку, сучасного технічного оснащення й обслуговування, а 3 іншого, не менш важливого - глобального підвищення рівня культури взаємин в усіх ланках транспортної системи.

Отже, уявити собі державне регулювання публічного управління i адміністрування поза людинознавчими функціями та врахування людського фактора неможливо. Але сутність і зміст цієї функції в теорії управління ще не пізнано й не розкрито. Існує парадокс: державне управління здійснюють конкретні особистості, люди, а їхня роль у цьому процесі залишається поза увагою теорії управління, яку вони самі й розробляють. До того ж, їхні дії, сукупність їхніх рішень ще не $\epsilon$ сутністю, а тільки формою їх вияву.

3 кожним поступом людської цивілізації у всіх динамічних змінах i перетвореннях на перший план виступає людина як суб'єкт, як творець, як носій нових якостей, культурного потенціалу, що так яскраво проявляється у злетах техніки, науки, культури тощо. Але цей процес затьмарюють численні факти падіння духовності, занедбаності, жорстокості, а подекуди навіть варварства. З'явилася потреба глибоко проаналізувати причини такого явища, дослідити механізми державного регулювання процесу розв'язання та подолання вказаних суперечностей. Держава, як соціальна інституція, яка покликана забезпечити управління суспільством, спираючись на відповідні структури управління, має справу не 3 механізмами, а конкретними людьми, управлінцями.

Стан та ефективність роботи Укрзалізниці як великої складової транспортної системи України, як відкритої системи, що постійно розвивається, $є$ визначальним для нормального функціонування всієї економіки.

Регулювання процесу перевезень у внутрішньому та міжнародному сполученнях, a також регулювання виробничо-господарської діяльності у сфері організації й забезпечення цього процесу залізницями $є$ визначальним для функціонування суспільного виробництва.

Отже, проведений аналіз функцій державного регулювання залізничного транспорту дозволив зробити такі висновки:

- особлива увага має бути відведена комунікаційній функції державного регулювання, яка має забезпечити цілісність, поінформованість і відкритість діяльності кожної підсистеми залізничної галузі, можливість більш оперативного технологічного взаємозбагачення та обміну перспективним передовим досвідом;

- особливої ваги набуває наукове обгрунтування специфіки залізничного транспорту як стратегічного об'єкта державного регулювання захисту не відомчих інтересів галузі, а інтересів споживача;

- глибоких наукових досліджень потребує сфера мало відомих, але особливо значущих в умовах ринку особливостей взаємовідносин підприємств залізничного транспорту й держави, сфера налагодження високопродуктивних виробничих людських відносин.

Остання функція державного регулювання розвитку залізничного транспорту вимагає пошуку науково обгрунтованих механізмів подолання існуючої суперечності, яка гальмує процес його розвитку, а саме: між інтересами держави щодо отримання максимальних

Вісник економіки транспорту і промисловості № 59, 2017 
надходжень до бюджету та іï роллю як захисника і виразника інтересів споживачів, між споживачем і суб'єктом регулювання; між інтересами виробника i споживача залізничних послуг.

Таким чином, сутність процесу державного регулювання публічного управління i адміністрування можна характеризувати, як удосконалення, недопущення (неефективності, недоцільності), усунення перешкод, впорядкування, унормування, влаштування, налагодження тощо. Можна довести, що кінцевим результатом вказаних дій з боку органів державної влади (вдосконалення, недопущення...) $є$ досягнення цілісності (точніше, певного рівня цілісності) об'єкта управління. Для державного регулювання така цілісність має досягатися в системі державної влади та управління усіма сферами суспільного життя та господарювання в системах різного масштабу.

Ураховуючи це, категорію державного регулювання можна визначити як процес підготовки, прийняття та впровадження рішень суб'єктів (органів) державної влади, які спрямовані на посилення внутрішньої цілісності об'єкта державного управління (як його часток, так i в цілому), на який ці рішення розповсюджуються.

Отже, виходячи 3 існуючих i найбільш поширених визначень державного регулювання, можна говорити про державне регулювання як поняття, яке характеризується, перш за все, організаційним змістом.

Зрозуміло, що транспортна система як предмет державного регулювання публічного управління і адміністрування , як складне динамічне, соціальне явище, як внутрішньо- системні та зовнішньосистемні відносини потребують глибокого теоретичного осмислення, мають стати предметом, темою окремого наукового дослідження, щоб з'ясувати з урахуванням світових і вітчизняних наукових здобутків сутність і зміст такого важливого поняття як “державне регулювання розвитку залізничного транспорту”.

Загальновідомо, що будь-яке державне регулювання розвитку транспортної системи здійснюється шляхом об'єднання, узгодження, організації, координації, контролю за допомогою владно-регулюючих заходів, колективних зусиль для досягнення конкретних цілей.

Слід підтримати думку В. Развадовського про те, що “функції державного регулювання транспортної системи мають наступні основні риси:

- $е$ зовнішнім проявом властивостей об'єкту регулювання суспільних відносин у транспортній сфері;

- мають цілеспрямований, уособлений та самостійний характер;

- $\epsilon$ об’єктивно необхідними для здійснення процесу регулювання;

- реалізуються певними методами;

- характеризують зміст діяльності щодо регулювання транспортної системи" [5].

I зовсім недивно, що саме в цій сфері державного регулювання розвитку залізничного транспорту на науковій основі існує багато невирішених, але уже заявлених самим життям i вирішальною долею залізничного транспорту в майбутній долі держави питань.

Нечіткість у визначенні концептуальної моделі та напрямків розвитку фундаментальних теоретичних досліджень, їхнього статусу, невизначеність новизни їх основних характеристик та специфіки породжує нерозуміння не лише методологічного, а й організаційнонаукового та навіть фінансового аспекту.

Розв'язання кожного 3 основних завдань Укрзалізниці, має передбачати:

- організацію злагодженої роботи залізниць і підприємств, задоволення потреб суспільного виробництва i населення в перевезеннях;

- управління процесом залізничних перевезень, регулювання у сфері організації та забезпечення цього процесу; 
- вирішення питань ефективного використання залізничного рухомого складу, його збереження, оновлення, ремонту, забезпечення матеріальнотехнічними та паливно-енергетичними ресурсами тощо вимагає оперативного проведення нової соціальної політики на залізничному транспорті, науково обгрунтованого державного регулювання й упровадження єдиної інвестиційної та технічної політики, регулювання розвитку й упровадженням досягнень науки з різних іiі галузей.

При цьому стан науково обгрунтованого забезпечення розвитку залізничного транспорту на сучасному етапі ринкових відносин вимагає не стільки імперативного державно-управлінського впливу на розвиток транспортної системи, стільки його централізованого державного регулювання. Мова йде про державне регулювання розвитку теоретичного й прикладного напрямку досліджень, розумне їх поєднання.

\begin{tabular}{llr}
\multicolumn{2}{c}{ Висновки .Маємо } & підсумувати \\
результати & наукових & досліджень \\
розглянутих & нами тлумачень сутності \\
досліджуваної & категорії й & констатувати \\
наступне: & державне & регулювання
\end{tabular}
публічного управління і адміністрування це управління будь-якими сферами залізничного транспорту - $з$ середини, яке вимагає, перш за все, від державних діячів вчасного усвідомлення глибинних змін сучасного наукового поля найважливіших, уже оновлених управлінських категорій, щоб не опинитись на узбіччі сучасної методологічної культури успішного впровадження нових механізмів цільового розвитку залізничного транспорту та уникнути розриву між теорією й практикою, не допустити формалізму та неузгодженості в забезпеченні цілісності розвитку залізничної галузі на тривалу перспективу 3 урахуванням об'єктивних реалій української економіки та законодавства.
Складність державного регулювання публічного управління i адміністрування розвитку залізничного транспорту України пов'язана 3 відсутністю чітко виділених концептуальних засад та критеріїв оцінювання його (розвитку) ефективності, відповідної методики, цього важливого в державному регулюванні процесу, яка б відповідала вимогам часу, стану науководослідних досягнень у цій сфері та достовірним результатам. Подальший пошук ефективної моделі управління i адміністрування галузі залізничних перевезень передбачає реалізацію передбачених законодавством України відповідних нормативних документів. Перспективи подальших досліджень саме i будуть присвячені цій невідкладній проблемі.

\section{СПИСОК ВИКОРИСТАНИХ ДЖЕРЕЛ}

1. Шепель В.М. Управленческая этика. - М.: Экономика, 1989. - 287 с.

2. Шакуров Р.X. Социальнопсихологические основы управления: руководитель и педагогический колектив. М.: Просвещение, 1990. - 208 с.

3. Марущак В.П. Державне управління та функції управління / Актуальні проблеми державного управління: зб. наук. пр. - Х.: Вид-во ХарРІ НАДУ “Магістр", 2008. - Вип. 1(27). - С. 1521.

4. Развадовський В.Й. Адміністративно-правові проблеми та шляхи їх розв'язання): дис... д-ра юрид наук: 12.00.07 / Національний університет внутрішніх справ. Х., 2014 - 466 с.

5.Сущенко Р.В. Залізничний транспорт як особливий об'єкт державного регулювання / Університетські наукові записки № 3(27). - 2008. Часопис Хмельницького університету управління та права. - С. 38-45.

6.Скворцов О.О. Формування механізму державного регулювання в перехідній економіці // Економіка: 
проблеми теорії та практики. - 2014. Випуск № 119. - С. 43-48.

7.Сорокин Г.М. Экономическая эффективность при социализме. - М.: Наука, 1979. - 335 c.
8.Сінгаєвська М.П. Економічна ефективність на підприємствах залізничного транспорту / Проблеми інформатизації та управління. - 2015. - № 13. - C. $41-51$

УДК 658:656.2(477)

\title{
СТРАТЕГІЧНИЙ МЕНЕДЖМЕНТ ТА ЙОГО ВИКОРИСТАННЯ В ПРАКТИЦІ ФОРМУВАННЯ І ДОСЯГНЕННЯ ЦІЛЕЙ РОЗВИТКУ ЗАЛІЗНИЧНОГО ТРАНСПОРТУ
}

\author{
Дикань О. В., д.е.н., професор, \\ Смаль О.В., магістрант програми ТЕМПУС (УкрДУЗТ)
}

\begin{abstract}
В статі встановлено, щуо на сьогодні в залізничній галузі максимально загострюється актуальність питання залучення нових стратегічних підходів та методів до галузевих економічних прочесів. Від іх розвитку залежать результати роботи підприємств, тому проблеми розвитку методів стратегічного менеджменту та іх використання в практиці формування $i$ досягнення цілей залізничного транспорту є актуальними.

Для визначення особливостей використання стратегічного менеджменту в статті управління залізничним транспортом досліджено існуючий теоретичний базис з окресленої тематики. Встановлено, щуо існуюча стратегія розвитку залізничного транспорту має тактичне спрямування, а не стратегічне. Визначені напрямки та передумови удосконалення теоретичного базису стратегічного менеджменту на залізничному транспорті Украӥни.
\end{abstract}

Ключові слова: стратегічний менеджмент, ринкова економіка, стратегічний аналіз, управління, залізничний транспорт.

\section{СТРАТЕГИЧЕСКИЙ МЕНЕДЖМЕНТ И ЕГО ИСПОЛЬЗОВАНИЕ В ПРАКТИКЕ ФОРМИРОВАНИЯ И ДОСТИЖЕНИЯ ЦЕЛЕЙ РАЗВИТИЯ ЖЕЛЕЗНОДОРОЖНОГО ТРАНСПОРТА}

\author{
Дикань Е.В. д.э.н., профессор, \\ Смаль А.В., магистрант программы ТЕМПУС (УкрГУЖТ)
}

В статье установлено, что сегодня в железнодорожной отрасли максимально обостряется актуальность вопроса привлечения новых стратегических подходов и методов в отраслевых экономических процессах. От их развития зависят результаты работь предприятий, поэтому проблемь развития методов стратегического менеджмента и их использование в практике формирования и достижения иелей железнодорожного транспорта являются актуальными.

(C) Дикань O.B.,

Смаль О.В.
Вісник економіки транспорту і промисловості № 59, 2017 